\title{
Effect of Welding Processes on Mechanical and Metallurgical Properties of High Strength Low Alloy (HSLA) Steel Joints
}

\author{
D.Aravind Kumar \\ Assistant Professor \\ Department of Mechanical Engg \\ Ganesh College of Engineering, Salem \\ A.Balamurugan \\ Assistant Professor \\ Department of Mechanical Engg \\ Ganesh College of Engineering, Salem \\ E.Venkatesan \\ Assistant Professor \\ Department of Mechanical Engg \\ Ganesh College of Engineering, Salem \\ T.Ram Kumar \\ Assistant Professor \\ Department of Mechanical Engg \\ Sri shanmuga College of Engineering and Technology, Salem
}

\begin{abstract}
High Strength Low Alloy (HSLA) steels were developed primarily for the automotive industry to replace lowcarbon steels in order to improve the strength-to-weight ratio and meet the need for higher-strength construction grade materials. During this period, micro-alloyed or HSLA steels became an indispensable class for different applications like automobile industry, ship building, line pipe, pressure vessels, building construction, bridges, and storage tanks. Different welding techniques are used in this study to evaluate the mechanical properties of weldments of HSLA steel. Weldments are prepared using three welding processes such as shielded metal arc welding (SMAW), flux cored arc welding (FCAW) and friction stir welding (FSW). Friction stir welding (FSW) is a solid state technology that has attracted considerable interest since it was invented at TWI in 1991. Structural integrity issues in welding of HSLA steels are associated with different problems encountered in friction stir welding of these steels. The other important problem in welding HSLA steels is to prevent brittle fracture of welded joints due to increased strength of HSLA steels. The solid state characteristics of FSW eliminate the susceptibility of porosity and cracking. The objective is to determine the best welding process for HSLA steel by evaluating weld metal microstructure and mechanical properties including weld metal tensile strength and Charpy $\mathrm{V}$-notch impact toughness are investigated. Charpy impact and tensile tests are performed on standard notched specimens obtained from the welded and main sections of the material. The hardness distribution measurements on the differently welded specimens are conducted in order to gain a deep insight of different welding processes.
\end{abstract}

Keywords: Shielded metal arc welding; Flux cored arc welding; Friction stir welding; High strength low alloy steel; Tensile Properties;

\section{INTRODUCTION}

Structural integrity issues in welding of HSLA steels are associated with different problems encountered in fusion welding of these steels. These problems are cracking, residual stresses, distortion and fatigue damage. Among all the problems encountered during welding; cracking is the most common. The other important problem in welding 
HSLA steels is to prevent brittle fracture of welded joints due to increased strength of HSLA steels. Brittle fracture is caused by structural transformations in the welded joint and the heat-affected zone (HAZ) and also by impurities dissolved in the metal mainly due to hydrogen. The solid state characteristics of FSW attracted considerable interest due to the elimination of the susceptibility of porosity and cracking. HSLA steels became an indispensable class for different applications like automobile industry, ship building, and pipe line, pressure vessels, building construction, bridges and storage tanks.

Welding HSLA Steels of these classes of high impact resistance require strict welding conditions to realize their characteristic potential also in the welds and in their heat affected zone (HAZ). The solid state characteristics of FSW attracted considerable interest due to the elimination of the susceptibility of porosity and cracking. Friction stir welding (FSW) is a relatively new solid state joining process and is the focus of constant attention in joining low and high temperature materials [1]. FSW has appeared as an easy, ecological and promising productive welding method that reduces material waste and avoids radiation and harmful gas emissions, usually associated with the fusion welding processes [2]. FSW technology has been extensively implemented in the fabrication of aluminium structure components for space vehicles, aircraft, automotive, and naval applications. Though FSW process is successful in joining these relatively soft materials and expanding the application of this process to harder, stronger materials such as carbon steels, stainless steels, and titanium alloys, it has proven difficult owing to the propensity of the tool to degrade during the welding process [3].

Much of the degradation may be attributed to the high heat (temperature of around $1200^{\circ} \mathrm{C}$ and stresses generated during friction stir welding of these high strength materials [4]. However, the development of wear resistant tool materials will benefit the FSW process and pave way for the rapid implementation in the fabrication of ferrous structures and structures made from other refractory materials. Recently, there has been considerable interest in exploring the use of FSW for joining steels and other higher-melting temperature materials. Many fundamental aspects of the process still remain unanswered, e. g. the bonding nature of joint and materials flow pattern during welding [5]. Few papers (6-15) are available on friction stir welded carbon steels, but there is a need for further experimental research to understand the fundamental mechanisms associated with the weld formation process and the welding quality. Hence, this preliminary investigation was carried out to understand the microstructural changes, tensile and impact toughness properties and fracture location of friction stir welded HSLA steel and compare these characteristics with SMAW and FCAW joints.

\section{EXPERIMENTAL}

The rolled plates of HSLA steel with thickness of $5 \mathrm{~mm}$ were cut to the required dimensions $(100 \mathrm{~mm} \times$ $150 \mathrm{~mm}$ ) by abrasive cutting as shown in the Fig. 1a. The chemical composition and mechanical properties of HSLA steel are provided in Table 1 and 2 respectively.

Table 1 Chemical composition of base metal

\begin{tabular}{|c|c|c|c|c|c|c|c|c|c|c|c|c|c|c|}
\hline $\mathbf{C}$ & $\mathbf{M n}$ & $\mathbf{P}$ & $\mathbf{S}$ & $\mathbf{N}$ & $\mathbf{S i}$ & $\mathbf{C r}$ & $\mathbf{M o}$ & $\mathbf{T i}$ & $\mathbf{V}$ & $\mathbf{N b}$ & $\mathbf{N i}$ & $\mathbf{C u}$ & $\mathbf{A l}$ & $\mathbf{W}$ \\
\hline $\begin{array}{c}\mathbf{0 . 0} \\
\mathbf{8}\end{array}$ & $\mathbf{1 . 4 2}$ & 0.006 & 0.001 & 0.015 & $\mathbf{0 . 1 9}$ & 0.001 & 0.02 & 0.016 & 0.032 & 0.035 & $\mathbf{0 . 6 9}$ & $\mathbf{0 . 1 2 6}$ & 0.032 & 0.04 \\
\hline
\end{tabular}

Table 2 Mechanical properties of base metal

\begin{tabular}{|c|c|c|c|c|c|}
\hline $\begin{array}{c}\mathbf{0 . 2 \%} \text { offset } \\
\text { Yield Strength } \\
\text { (MPa) }\end{array}$ & $\begin{array}{c}\text { Ultimate Tensile } \\
\text { Strength (MPa) }\end{array}$ & $\begin{array}{c}\text { Elongation (\%) } \\
\text { in 25 mm gauge } \\
\text { length }\end{array}$ & $\begin{array}{c}\text { Impact } \\
\text { Toughness in } \\
(\mathbf{J}) @ \text { RT }\end{array}$ & $\begin{array}{c}\text { Hardness of base } \\
\text { metal @ 0.5 kg load } \\
\text { (HV) }\end{array}$ & $\begin{array}{c}\text { Fracture } \\
\text { Location }\end{array}$ \\
\hline 594 & 638 & 20 & 61 & 270 & Centre \\
\hline
\end{tabular}

The microstructure of parent metal (Fig.1c) is composed of ferrite, and few pearlite. A nonconsumable rotating tool made of tungsten based alloy shown in Fig.1d was used to fabricate FSW joints. The tool was manufactured through powder metallurgy route having a shoulder diameter of $24 \mathrm{~mm}$ and a tapered pin, tapering from $12 \mathrm{~mm}$ at the shoulder to $8 \mathrm{~mm}$ at the pin tip. Trial experiments and macro structural analysis were carried out to find out the feasible range of FSW process parameters. Thermocouple located at Advancing Side and Retreating Side of the middle plate and it was interfaced with Lab View software to record the heat generated during welding (figure e,f). 


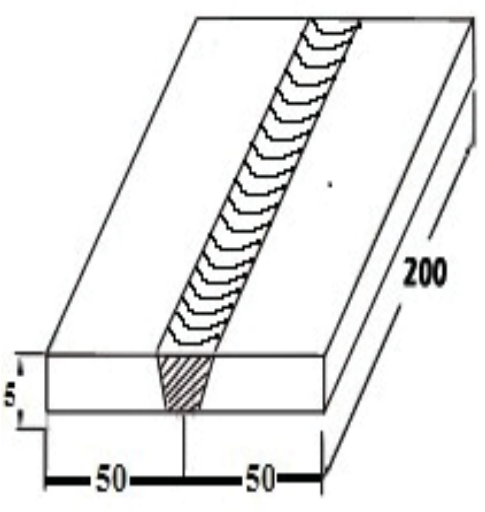

All dimensions are in mm

Figure 1a: Joint design

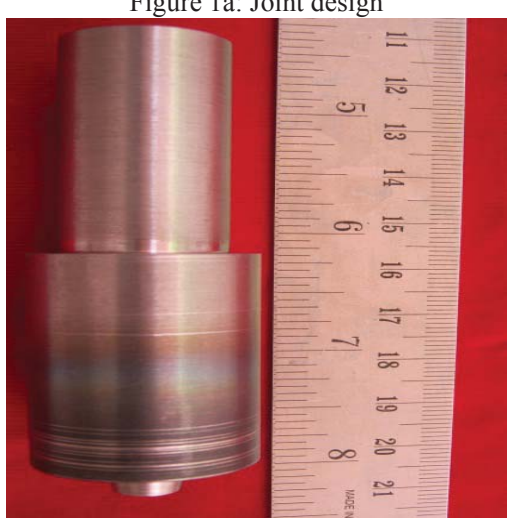

Figure 1d: Tungsten based alloy tool

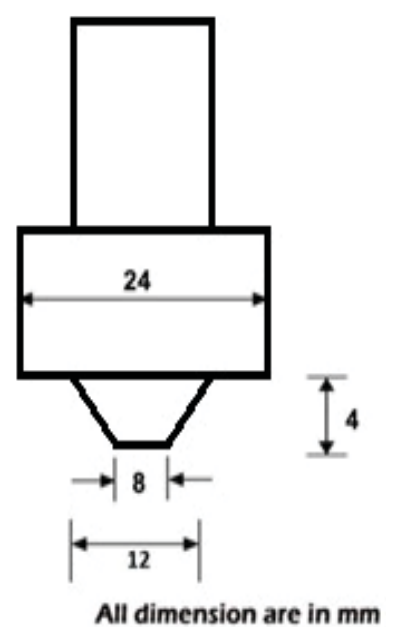

Figure 1b: Tool design

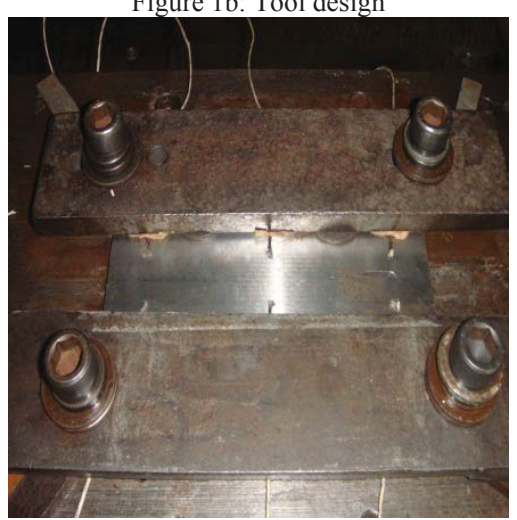

Figure 1e: Thermocouple location

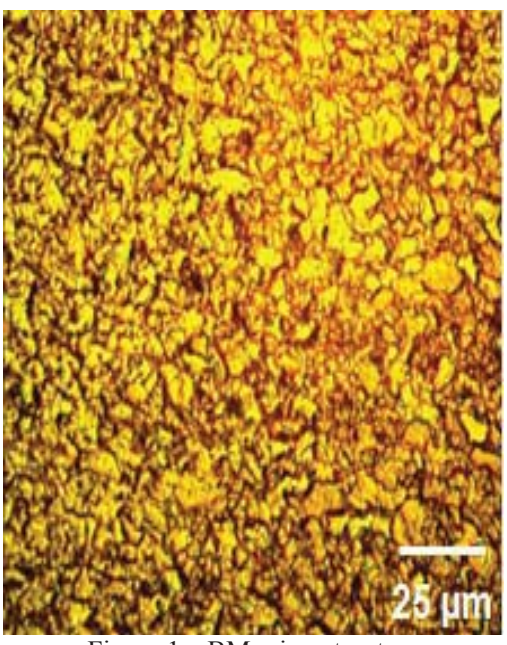

Figure 1c: BM microstructure

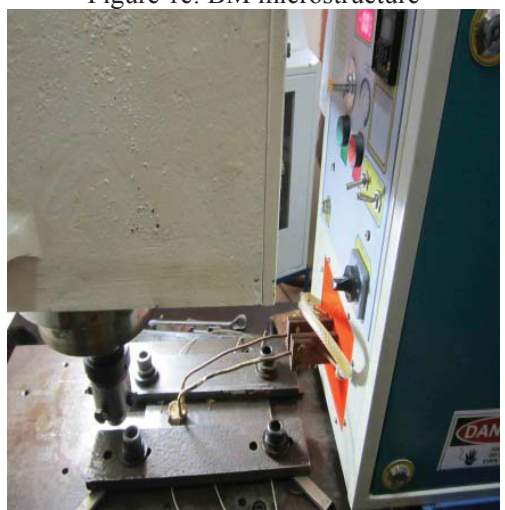

Figure 1f: Induction Preheating Source

Figure 1: Photograph of Joint design, Tool design, BM microstructure Tool, Thermocouple location, and Preheating source

The welding conditions and parameters (to get defect free welds) presented in Table 3 and 4 were used to fabricate the joints for further investigation. The welded joint is displayed in Figure 2 ( $a, b$ and c). ASTM E8M-04 guidelines were followed for preparing the test specimens. Tensile test specimens were prepared to evaluate the transverse tensile properties such as yield strength, tensile strength, and elongation. Electromechanical controlled universal testing machine (Make: FIE Bluestar, India; Model: UNITEK-94100) of $100 \mathrm{kN}$ capacity was used for tensile testing in each condition, three specimens were tested and the average is presented.

Table 3 FSW conditions and parameters

\begin{tabular}{|c|c|c|c|c|c|}
\hline Joint Name & $\begin{array}{c}\text { Preheating } \\
\text { Temperature } \\
\left({ }^{0} \mathrm{C}\right)\end{array}$ & $\begin{array}{c}\text { Tool Rotational } \\
\text { Speed }(\mathrm{rpm})\end{array}$ & $\begin{array}{c}\text { Welding Speed } \\
(\mathrm{mm} / \mathrm{s})\end{array}$ & Axial Force $(\mathrm{kN})$ & $\begin{array}{c}\text { Heat input, } \\
\mathrm{kJ} / \mathrm{mm}\end{array}$ \\
\hline Joint-A & 100 & 600 & 30 & 15 & 1.58 \\
\hline
\end{tabular}


Table 4 SMA and FCA welding conditions and parameters

\begin{tabular}{|l|c|c|}
\hline \multicolumn{1}{|c|}{ PARAMETER } & SMAW & FCAW \\
\hline Preheating temperature $/{ }^{\circ} \mathrm{C}$ & 100 & 100 \\
\hline Electrode Baking temperature $/{ }^{\circ} \mathrm{C}$ & 300 & ---- \\
\hline $\mathrm{CO}_{2}$ gas flow rate $/\left(\mathrm{L}_{\mathrm{min}}{ }^{-1}\right)$ & ---- & 12 \\
\hline Filler diameter $/ \mathrm{mm}$ & 4 & 1.6 \\
\hline Current $/ \mathrm{A}$ & 113 & 105 \\
\hline Voltage $/ \mathrm{V}$ & 23 & 20 \\
\hline Heat input, $\mathrm{kJ} / \mathrm{mm}$ & 1.13 & 1.4 \\
\hline
\end{tabular}

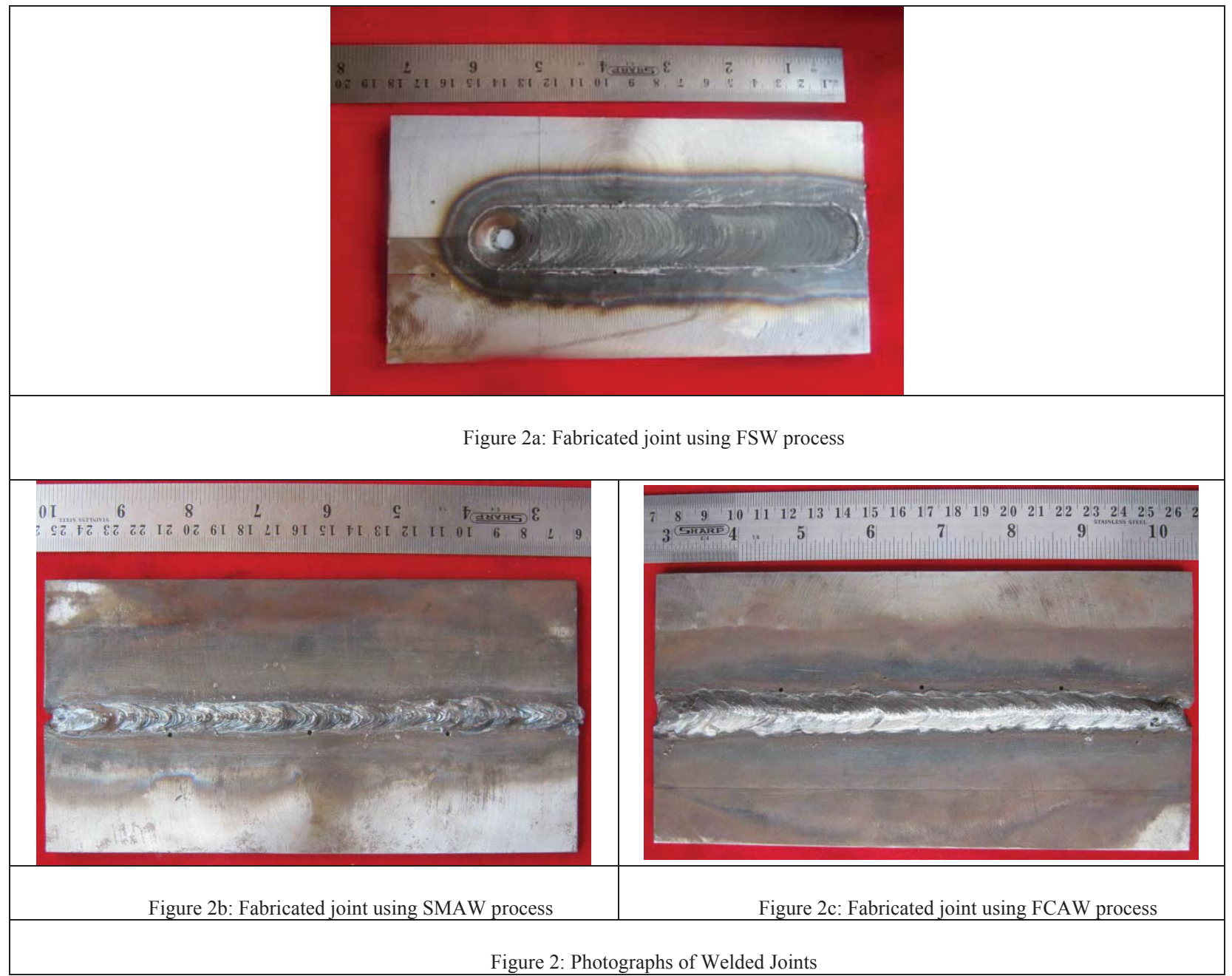

Charpy impact specimens were prepared to the dimensions shown in Fig. $2 b$ to evaluate the impact toughness of the weld metal and hence the notch was placed (machined) at the weld metal (weld center) as shown in Fig. 3. The plate thickness was small and sub size specimens were prepared. Impact testing was conducted at room temperature using a pendulum-type impact testing machine (Enkay, India). The amount of energy absorbed in fracture was recorded, and the absorbed energy is defined as the impact toughness of the material. ASTM E23-04 guidelines were followed for preparing and testing the impact specimens. Vicker's microhardness tester (Make: Shimadzu, Japan and Model: HMV-2T was used for measuring the hardness of the weld metal with a load of $0.5 \mathrm{~N}$ for $15 \mathrm{~s}$. The specimens for metallographic examination were sectioned to the required sizes from the joint comprising weld metal, HAZ (heat-affected zone), and base metal regions and polished using different grades of 
emery papers. Final polishing was done using the diamond compound (1 pm of particle size) in the disc polishing machine. Specimens were etched with $5 \%$ of Nital solution to reveal the microstructure of FSW joints.

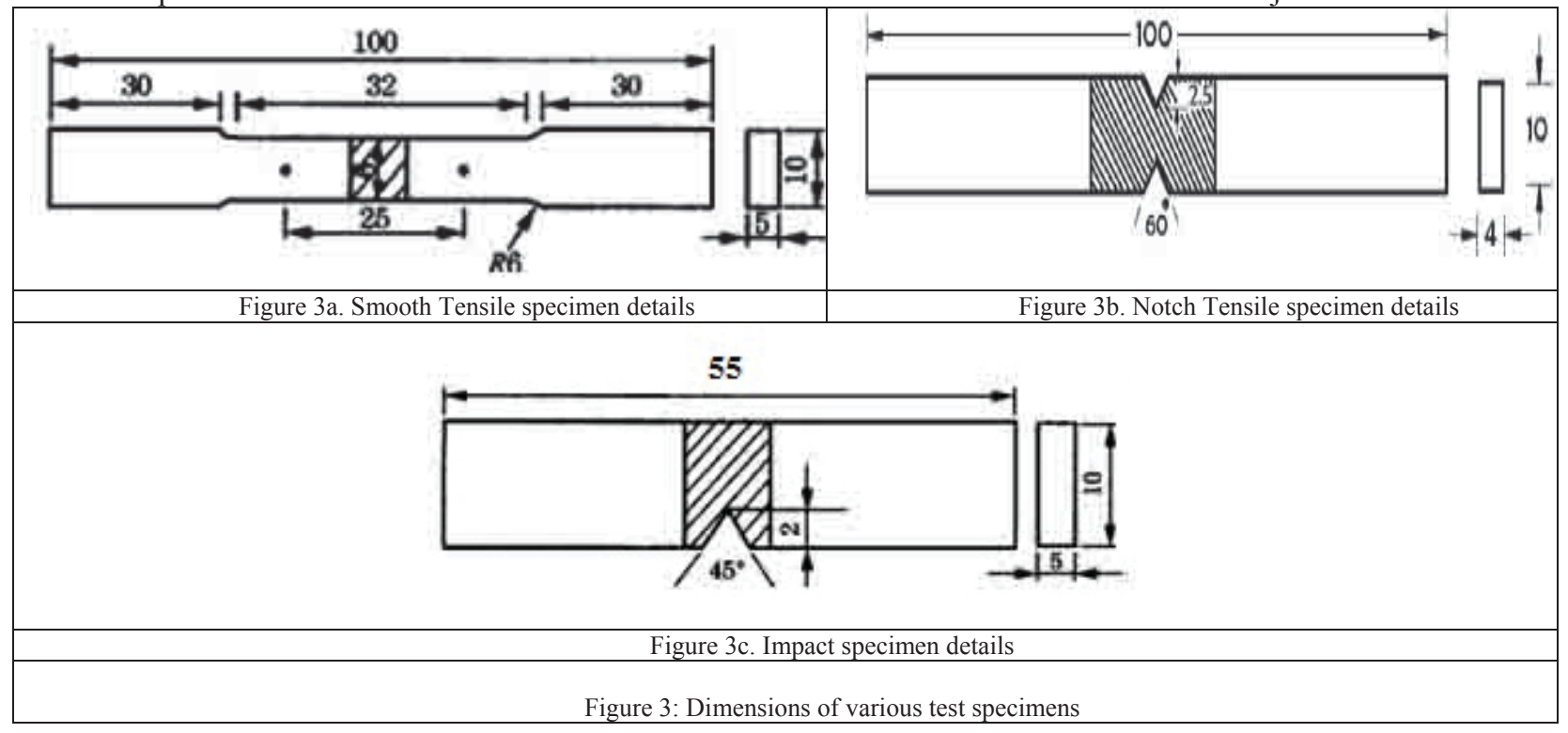

Micrograph examination was carried out using a light optical microscope (Make: MEJI, Japan; Model: MIL-7100) incorporated with an image analyzing software (Metal Vision).

\section{RESULTS AND DISCUSSION}

\subsection{Tensile and Impact Toughness Properties}

Table 5 presents the transverse tensile properties of the welded joints. In each condition three tensile specimens were tested in each joint and the average is presented in Table 5.

Table 5 Transverse tensile and impact properties of the joints

\begin{tabular}{|c|c|c|c|c|c|c|c|c|}
\hline Joint & $\begin{array}{c}0.2 \% \\
\text { offset } \\
\text { Yield } \\
\text { Strength } \\
(\mathrm{MPa})\end{array}$ & $\begin{array}{c}\text { Ultimate } \\
\text { Tensile } \\
\text { Strength } \\
(\mathrm{MPa})\end{array}$ & $\begin{array}{c}\text { Notch } \\
\text { tensile } \\
\text { strength } \\
(\mathrm{MPa})\end{array}$ & $\begin{array}{c}\text { NSR } \\
\text { ratio }\end{array}$ & $\begin{array}{c}\text { Elongation } \\
(\%) \text { in 25 } \\
\text { mm gauge } \\
\text { length }\end{array}$ & $\begin{array}{c}\text { Impact } \\
\text { Toughness } \\
\text { in (J) @ RT }\end{array}$ & $\begin{array}{c}\text { Hardness } \\
\text { of weld } \\
\text { metal @ } \\
0.5 \mathrm{~kg} \text { load } \\
\text { (HV) }\end{array}$ & $\begin{array}{c}\text { Fracture } \\
\text { Location }\end{array}$ \\
\hline FSW & 525 & 595 & 740 & 1.24 & 10 & 36 & 380 & BM \\
\hline SMAW & $\mathbf{5 3 6}$ & $\mathbf{6 1 0}$ & $\mathbf{9 2 2}$ & $\mathbf{1 . 5 1}$ & $\mathbf{1 6}$ & $\mathbf{2 1}$ & $\mathbf{3 5 6}$ & BM \\
\hline FCAW & 515 & 588 & 885 & 1.50 & 13 & 19 & 334 & BM \\
\hline
\end{tabular}

The yield strength and tensile strength of unwelded parent metal are $594 \mathrm{MPa}$ and $638 \mathrm{MPa}$ respectively. But the yield strength and tensile strength of friction stir welded are $525 \mathrm{MPa}$ and $595 \mathrm{MPa}$, respectively. This indicates that there is a $7 \%$ reduction in strength values due to an increase in prior-austenite grain size in reheated and isothermally held specimens [6]. Similarly, the yield strength and tensile strength of shielded metal arc welded joints are $536 \mathrm{MPa}$ and $610 \mathrm{MPa}$, which are $4.5 \%$ lower compared to parent metal. However, the yield strength and tensile strength of flux cored arc welded joints are $515 \mathrm{MPa}$ and $588 \mathrm{MPa}$, which are $8 \%$ respectively. Spanos et al. used dilatometer and high-resolution microscopy, confirming the presence of acicular ferrite and lath martensite as a function of peak temperature and cooling rate during welding [7]. Of the three types of welded joints, the joints fabricated shielded metal arc welding process exhibited higher strength values.

During tensile test, all the specimens invariably failed in the unwelded region. This indicates that the weld region is comparatively stronger than other regions and that the joint properties are controlled by weld region chemical composition and microstructure. Fonda et al. observed higher hardness in areas where the prior-austenite grain size was relatively smaller than that close to the fusion line [11]. Inclusion of tungsten in the pin influenced 
region resulted in the reduction of ductility and impact toughness of the weld metal. Three charpy impact toughness test specimen results were averaged and the results are presented in Table 5. The impact properties of base metal is $62 \mathrm{~J} @$ room temperature, when it welded with FSW process, the weld metal exhibited $36 \mathrm{~J}$ which is $40 \%$ lower than the base metal and the lowest impact strength was achieved in the joints fabricated by fusion welding process compared with the FSW process.

\subsection{Hardness}

The hardness across the weld cross section was measured using a Vickers Micro-hardness testing machine, and the values are presented in Figure 5. The hardness of base metal (unwelded parent metal) in its initial condition is $270 \mathrm{VHN}$. But the hardness of the joints made by FSW, SMAW, and FCAW process are in the weld metal region were 406, 298 and 285 VHN respectively.

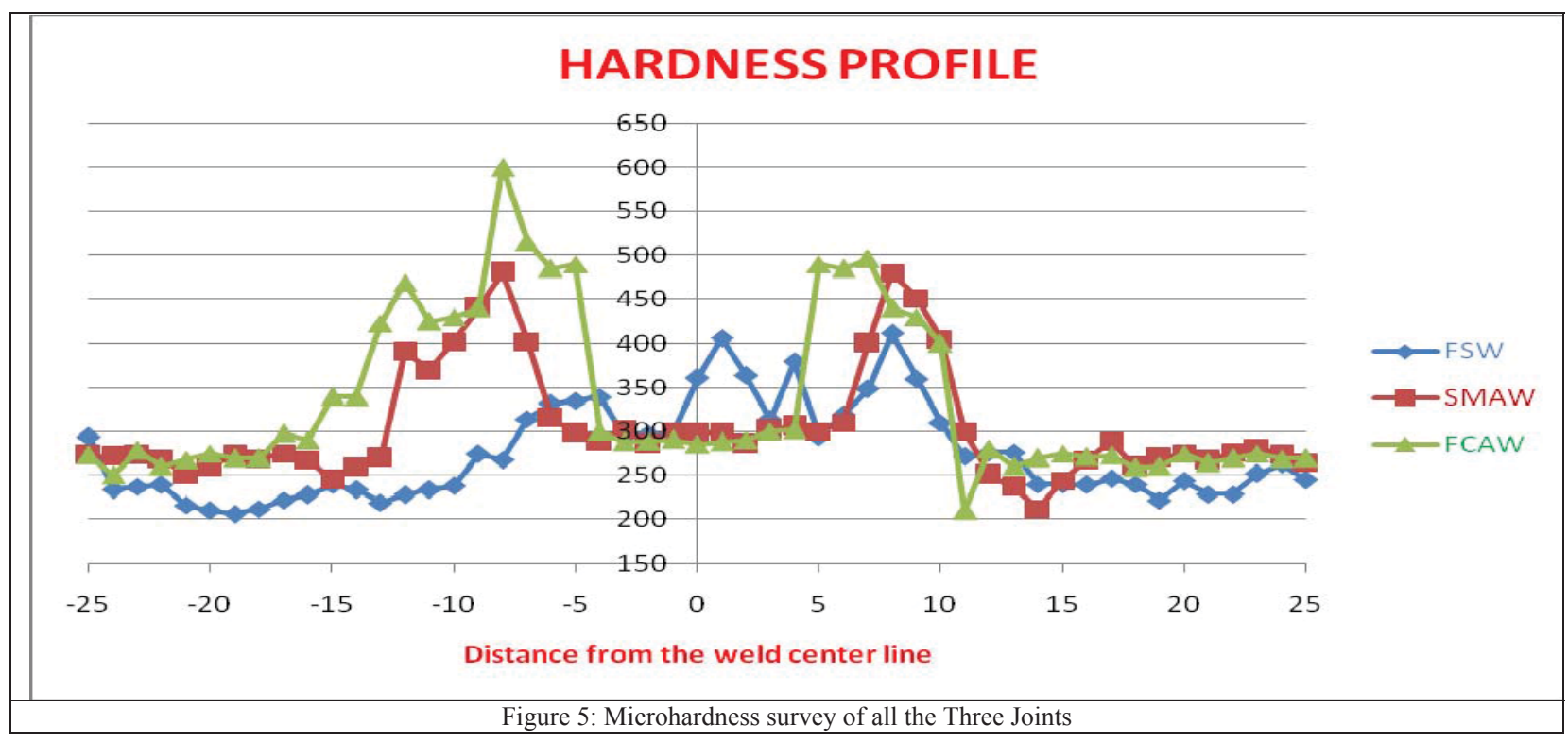

This suggests that the hardness is increased in the weld metal region of joint made by friction stir welding process due to welding thermal cycle. Fig.5 shows the hardness variations across the weld. The micro hardness decreases from Centre of welded joint to matrix invariably in all the three joints. From Fig.5 (moving from left to right WM, HAZ and $\mathrm{BM}$ ), it can be understand that the raise in micro hardness value in the weld zone and the falling of hardness value towards the base metal is due to the presence of coarse distorted micro structure invariably in all the three joints. The hardness profile (Fig.5) shows the welded joints are in agreement with the resultant strength properties at intermediate and highest strength levels respectively.

\subsection{Macrostructure and Microstructure}




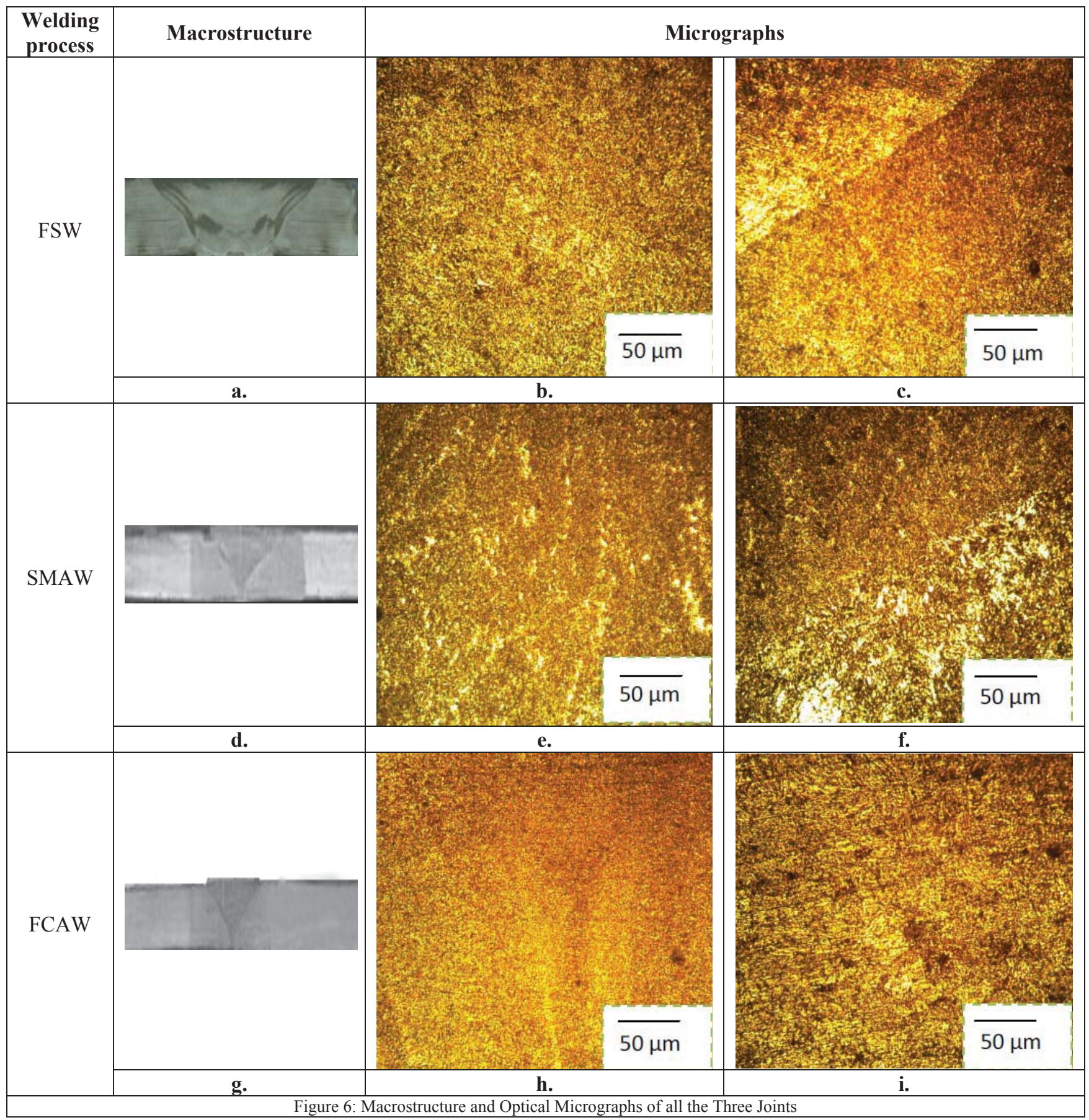

The macrostructure of the FSW joint was displayed in Figure 6. There is no macro level defect at the cross section of welded joints. The availability of different zones is clearly visible. Figure 6 (a-i) represents the macrostructures and microstructures of different locations of FSW, SMAW, and FCAW joints namely advancing side heat affected zone (ASHAZ), advancing side thermo mechanically affected zone (ASTMAZ), stir zone (SZ), retreating side thermo mechanically affected zone (RSTMAZ), retreating side heat affected zone (RSHAZ), weld metal (WZ), heat affected zone (HAZ) respectively. 
Figure a-b shows macrostructure and microstructures of the various regions in the friction stir welded joint and figure d-f are the corresponding macro and microstructures of the shielded metal arc welding respectively. Similarly, figure g-i is the corresponding macro and microstructures of the flux cored arc welding respectively. Since, the intense of heat and mechanical action is more in the TMAZ and SZ both Advancing Side (AS) and Retreating Side (RS) of the FSW joint. So, the micro structural fruition in these zones is considered to be discussed initially. The ASTMAZ microstructure presented in Figure $6 \mathrm{~b}$ reveals the sudden change in grain orientation due to the metal excavation from this zone to deposit in the retreating side. Whereas in SZ shows the presence of fine ferrite laths dispersed in bainitic matrix is clearly visible in Figure 6c. The microstructure taken at the weld metal and interface region of shielded metal arc welded joint which consists of accicular ferrite morphology figure $6 \mathrm{f}$ and g. (Figure 6h) In the WZ microstructure of joint welded flux cored arc welding was clearly depicts the presence of sudden change in orientation of grains and coarse columnar ferrite attributed to the higher heat and mechanical action involved in this region. Figure 6i represents the microstructure of HAZ at this higher heat results coarse ferrite laths with bainitic structures.

\section{CONCLUSIONS}

In this investigation, an attempt was made to identify the best welding process for HSLA steel by evaluating weld metal microstructure and mechanical properties including weld metal tensile strength and Charpy V-notch impact toughness. From this investigation, the following important conclusions are derived:

(i) Of the three welded joints, the joints fabricated by shielded metal arc welding process exhibited higher strength values and the enhancement in strength value is approximately $20 \%$ compared to joints made by FCAW and FSW processes due to the presence of retained austenite located between bainite packets whereas lath martensite located at prior austenite grain boundaries. The retained austenite could be the key for the enhancement of the tensile strength of this joint.

(ii) Of the three joints fabricated, joints fabricated by FSW process exhibited $50 \%$ higher impact toughness compared to the joints fabricated by fusion welding processes and this is due to the amount of M-A constituents and the ferrite laths in bainitic matrix.

(iii) A refractory tungsten based tool was successfully used to make butt-joint weld in $5 \mathrm{~mm}$ thick HSLA steel. However pin and the shoulder exhibited severe plastic deformation and excessive wear after weld length.

(iv) The present trials indicate that FSW is technically feasible for joining HSLA steel for a desirable combination of high strength and without compromising the impact toughness properties.

\section{ACKNOWLEDGEMENTS}

The authors wish to thank Naval Materials Research Laboratory (NMRL), Ambernath for providing base metal HSLA steel. Also the authors are greatful to thank Mailam India Pvt. Ltd. for providing welding consumables.

\section{REFERENCES}

[1] Fujii H, Cui L, Tsuji N, et al. Friction Stir Welding of Carbon Steels [J]. Mater Sci Eng, 2006, 429A(1/2) : 50

[2] Enomoto M. Friction Stir Welding: Research and Industrial Applications [J]. Weld Int, 2003, 17(5): 341.

[3] Park S H C, Sato Y S, Kokawa H, et al. Ebride Formation Induced by pcBN Tool Wear in Friction-Stirwelded Stainless

[4] Gan W, Li Z T, Khurana S. Tool Materials Selection for Friction Stir Welding of L80 Steel [J]. Sci Tech Weld Join, 2007,12(7) 610.

[5] Zhu X K, Chao Y J. Numerical Simulation of Transient Temperature and Residual Stresses in Friction Stir Welding of 304L Stainless Steel [J]. J Mater Process Technol , 2004, 146(2): 263.

[6] S.W. Thompson: 40th MWSP Conf. Proc., ISS, Warrendale, PA, 1998, pp. 663-73.

[7] G. Spanos, R.W. Fonda, R.A. Vandermeer, and A. Matuszeski: Metall. Mater. Trans. A, 1995, vol. 26A, pp. 3277-93.

[8] O. Grong: Metallurgical Modelling of Welding, The Institute of Materials, London, 1997, pp. 409-11.

[9] C.E. Cross, O. Grong, S. Liu, and J.F. Capes: in Applied Metallography, G.F. Vander Voort, ed., Van Nostrand Reinhold, New York, NY, 1986,pp. 197-210.

[10] P.L. Harrison and R.A. Farrar: Int. Mater. Rev., 1989, vol. 34, pp. 35-51.

[11] R.W. Fonda, G. Spanos, and R.A. Vandermeer: Proc. 4th Int. Conf. on Trends in Welding Research, ASM INTERNATIONAL, Materials Park, OH, 1995, pp. 277-82.

[12] O.R. Myhr and O. Grong: Acta Metall. Mater., 1990, vol. 38, pp. 449-60.

[13] L.E. Svensson: Control of Microstructures and Properties in Steel Arc Welds, CRC Press, Boca Raton, FL, 1994, pp.101-06. 
[14] S. Ravi, V. Balasubramanian, and S. Nemat Nasser, Fatigue Life Prediction of Strength Mis-matched High Strength Low Alloy Steel Welds, Mater. Des., 2006, 27, p 278-286

[15] R.E. Dolby: Weld. J., 1979, vol. 58, pp. 225s-238s.

[16] D. Radaj: Heat Effects of Welding, Springer-Verlag Publications, Heidelberg, 1992, pp. 100-03.

[17] J.C. Ion, K.E. Easterling, and M.F. Ashby: Acta Metall., 1984, vol. 32, pp. 1949-62.

[18] M.R. Krishnadev, J.T. Bowker, J.T. McGrath, V.K. Vasudevan, and K.D. Challenger: Proc. 2nd Int. Conf. on Trends in Welding Research, ASM INTERNATIONAL, Materials Park, OH, 1989, pp. 799-803.

[19] M.R. Krishnadev, W.L. Zhang, and J.T. Bowker: Proc. 3rd Int. Conf. on Welding Research, ASM INTERNATIONAL, Materials Park, OH, 1992, pp. 599-603.

[20] V. Balasubramanian and B. Guha: Sci. Technol. Weld. Join., 1999, 4, 265. 